\title{
MITIGATION OF DISASTER RISK REDUCTION IN PANGANDARAN REGENCY
}

\author{
Ramadhan Pancasilawan, Sawitri Budi Utami, Asep Sumaryana, \\ Slamet Usman Ismanto, and Destia Rosmalasari
}

Departement of Public Administration, Faculty of Social Science and political Science, Universitas Padjadjaran Email: ramadhan.pancasilawan@unpad.ac.id

\begin{abstract}
The government has a function to protect its people, including managing the disaster. The purpose of government in natural disaster management is a function that is expected to be carried out with full commitment. Disaster management is an activity carried out comprehensively, and there is a need for active stakeholder involvement. Pangandaran Regency is a disaster-prone area in West Java Province. This article aims to describe the mitigation launched by the Pangandaran Regency government to reduce disaster risk. The method used is qualitative, which uses observation data collection techniques, literature studies, and interviews with informants consisting of government and community elements. Pangandaran Regency has been stretched to get out of the tsunami disaster that had occurred. Even mitigation efforts have been carried out with the involvement of various stakeholders in the Pangandaran Regency. With mitigation, disaster risk reduction can be made. Therefore the government should make efforts to overcome disaster risk through the Mitigation Program by the Regional Disaster Management Agency (BPBD/Badan Penanggulanan Bencana Daerah). Disaster mitigation in Pangandaran Regency consists of two types: Mitigation with a Structural approach and Non-Structural approach. A structural approach is focusing on physical development, such as the construction of temporary evacuation sites or the construction of an early warning system (EAS). Non-structural mitigation carried out in the form of non-physical development, such as disaster education to school children and also to the community through activities carried out by mothers. Disaster training is given to private parties so that they can understand their role when disaster strikes.
\end{abstract}

Key words: Disaster Risk Reduction; Mitigation; Structural Approach; Non-Structural Approach

\section{MITIGASI BENCANA DALAM PENGURANGAN RESIKO BENCANA (PRB) DI KABUPATEN PANGANDARAN}

\begin{abstract}
ABSTRAK. Pemerintah memiliki fungsi mengelola bencana untuk melindungi warganya. Tujuan penanggulangan bencana alam yang dilakukan pemerintah diharapkan dapat dilakukan dengan komitmen penuh. Manajemen bencana merupakan kegiatan yang dilakukan secara komprehensif, dan perlunya keterlibatan pemangku kepentingan secara aktif. Kabupaten Pangandaran adalah daerah rawan bencana di Provinsi Jawa Barat. Artikel ini bertujuan untuk menggambarkan mitigasi yang dilakukan pemerintah Kabupaten Pangandaran untuk mengurangi risiko bencana. Metode yang digunakan adalah kualitatif, dengan menggunakan teknik pengumpulan data observasi, studi literatur, dan wawancara dengan informan yang terdiri dari unsur pemerintah dan masyarakat. Kabupaten Pangandaran telah menggeliat keluar dari bencana tsunami yang pernah terjadi. Mitigasi telah dilakukan dengan melibatkan berbagai pemangku kepentingan di Kabupaten Pangandaran. Dengan mitigasi, pengurangan risiko bencana dapat dilakukan. Karena itu pemerintah terus berupaya mengatasi risiko bencana melalui Mitigasi oleh Badan Penanggulangan Bencana Daerah (BPBD). Mitigasi bencana di Kabupaten Pangandaran terdiri dari dua jenis: Mitigasi dengan pendekatan Struktural dan Pendekatan Non-Struktural. Pendekatan struktural berfokus pada pengembangan fisik, seperti pembangunan lokasi evakuasi sementara atau pembangunan sistem peringatan dini (EAS). Mitigasi non-struktural dilakukan dalam bentuk pengembangan non-fisik, seperti pendidikan bencana kepada anak-anak sekolah dan juga kepada masyarakat melalui kegiatan yang dilakukan oleh para ibu. Bahkan pihak swasta juga diberikan pelatihan mengenai penanggulangan bencana agar mereka dapat paham mengenai perannya ketika terjadi bencana.
\end{abstract}

Kata kunci: Pegurangan Resiko Bencana; Mitigasi; Pendekatan Struktural; Pendeatan Non-Struktural

\section{INTRODUCTION}

In 2012 was issued Law No. 21 about the establishment of Pangandaran Regency, which is the result of the expansion of the parent region of Ciamis. Pangandaran Regency has a unique topographic because it is located on the south coast of West Java and also directly adjacent to Cilacap regency of Central Java. Although situated on the beach, Pangandaran Regency has a highland structure of hills.

The broad coverage of Pangandaran Regency area is approximately $1,010.92 \mathrm{~km} 2$ consists of 10 sub-districts 93 villages, 427 of Small Villages, 915 of Rukun Warga, and 3,189 of Rukun Tetangga. Thus morphology of Pangandaran Regency has a complex land structure, from lowland, wavy to have mountainous land with altitude varying between $0-2000 \mathrm{~m}$ from sea level.

According to the IRBI (Indonesia Disaster Risk Index) data that Pangandaran has been ranked 17th Indonesia, and 6th in West Java as a disaster-prone area. This condition occurs due to Pangandaran beach classified as a region with a high risk of vulnerability to the tsunami. Some areas of Pangandaran Regency are located on the coast therefore based on the results of the research explained that Pangandaran Regency is located in West Java province, Indonesia (Sumaryana, Creating Sustainable Disaster Management Collaboration In Indonesia, 2019). The total area of Pangandaran Regency is $168,509 \mathrm{Ha}$ with a sea area of $67,340 \mathrm{Ha}$. The length of the coast of Pangandaran Regency is adequate and has the 
potential for coastal tourism, which is $91 \mathrm{Km}$. The total population of 392,817 people in 2017 , then continues to increase with an average number of around 2,000 people/ year. Because of its position in the collision of the IndoAustralian plate with the Eurasian plate, Pangandaran Regency has a very high potential for danger.

The geographical condition of Pangandaran Regency with all its uniqueness and potential for disaster has been proven by the occurrence of an earthquake followed by the tsunami on July 17, 2006, at 15:19 WIB. The coordinates of the quake are 9.33 South Latitude and 107.26 East longitude at a depth of $10 \mathrm{~km}$ from the sea, the epicenter of the earthquake occurred in the Indian Ocean south of Ciamis Regency, and the location of the epicenter was $245 \mathrm{~km}$ south of Tasikmalaya. An earthquake measuring 7.7 on the Richter scale even a few minutes after the earthquake, a tsunami occurred struck the coastline in Pangandaran Regency resulted in many victims of falling and substantial material losses.

With areas potentially impacted by natural disasters, disaster mitigation efforts are needed to reduce disaster risk. With disaster mitigation, the process of normalization or healing in disaster victims is even ready to rebuild the environment (Mulyadi, 2012).

According to law number 24 of the year 2007 on disaster management and government Regulation No. 21 of 2008 on disaster management, explaining that disaster mitigation is a set of efforts to mitigate risk Disaster, both through physical development and awareness and improvement of the ability to deal with disaster threats. Therefore disaster mitigation is a preventative solution.

Mitigation is not only done to see empirical potential only. Mitigation also contains planning to be implementable in the form of programs/activity or actions aimed at reducing disaster risk, either caused or associated with dangers due to human behavior and natural hazards. This process of planning in mitigation is an effective form of response to the disaster that occurs.

Disaster mitigation is a stage conducted in the early stages in the disaster management cycle as it existed in Law No 24 of 2007. Mitigation is carried out to see empirical conditions regarding disaster-prone areas so that that impacts can be reduced in the event of a disaster. Then mitigation becomes a step to arrange management in natural disaster management.

Disaster mitigation needs to be set at the policy drafting phase primarily in policy formulation (policy agenda) because it is assessed to be able to provide an introduction of problems that require that disaster mitigation problems have been defined. The need for government intervention to support the agenda has been determined (Faturahman, 2018).

Mitigation is interpreted as an effort to reduce and prevent the risk of loss of soul and property through structural and non-structural approaches (Nursa'ban, 2010). Structural mitigation is a disaster risk reduction effort through physical development and technical engineering of disaster-resistant buildings. In contrast, non-structural mitigation is a non-physical disaster risk reduction effort such as policies, Community empowerment, institutional strengthening, and caring (Sugiharyanto, 2014). In reducing disaster risk, non-structural mitigation is more sustainable because it provides security in the long term.

Then the understanding of structural and nonstructural approaches is also expressed by (Triana, 2017) that the mitigation and disaster reduction efforts can generally be divided into two activities, namely the mitigation efforts With structural approaches, and nonstructural mitigation. Structural mitigation is an effort or mitigation undertaken to minimize the impact of disasters through the development of physical infrastructures and using technological methods. Also, structural mitigation can be explained as an effort to mitigate catastrophic vulnerabilities employing physical events such as disasterresistant building technical engineering. Further nonstructural mitigation is a form of an effort to reduce the impact of a disaster can within the scope of policymaking efforts, such as making a regulation. The Disaster Management Act is a non-structural effort in the policy area of this mitigation.

By conducting a disaster mitigation approach, there is still a lot that can be done mainly to reduce disaster risk. As happened in Pangandaran, the mitigation is done knowledge for vulnerable people in the area of disasterprone. This paper is produced from research conducted with the essential question being: How is the mitigation that has been carried out in Pangandaran Regency? So that it can be described in-depth, the purpose of this paper is to describe the mitigation launched by the Pangandaran Regency government in reducing disaster risk.

\section{METHOD}

This article is the result of comprehensive research activities conducted in Pangandaran Regency. The method used is qualitative. This research is done by the authors to examine the problem more precisely and in detail. Consideration of authors using the qualitative method because this research aims to reveal comprehensively the complex issues relating to the mitigation of natural disasters in Pangandaran Regency.

Meanwhile, the analysis used is a descriptive method for discovering facts with an accurate interpretation of the nature of some phenomenon of the group or individual coming from the results of the invention to clarify the Phenomenon or social reality. This article presents a detailed description of the mitigations carried out in Pangandaran Regency. So descriptive research describes the types of people or social activities (Neuman, 2006).

Primary data sources were obtained by in-depth interviews with parties who understood and or as actors of the mitigation process carried out in Pangandaran 
Regency. The informants included the Head of the Regional Disaster Management Agency (BPBD/ Regional Disaster Management Agency) and three informants from the Operational Control and Information Center. Then two informants from Social Organizations concerned with the Pangandaran Disaster were Volunteers in the Village, several Community informants living on the Pangandaran Coast, three informants from the Hotel management, and several informants from tourists. Secondary data is obtained through documentation, mass media, and literature.

\section{RESULT AND ANALYSIS}

\section{Disaster risk in Pangandaran}

According to IRBI (Indonesian Disaster Risk Index), Pangandaran Regency is in the order of 16 disasterprone areas from 514 districts/cities in Indonesia. For the provincial level of West Java, Pangandaran Regency is in the 5th order.

Sourced from the official website BPBD Pangandaran Regency, the following is a frequent disaster in Pangandaran in the last ten years, including; Floods, tidal waves, drought, earthquakes, landslides, boar, and forest.

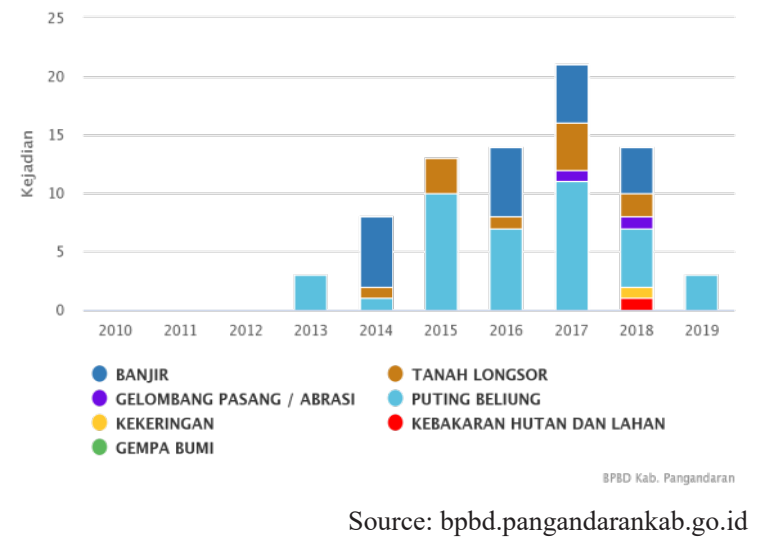

Picture 1. The trend of the last 10 years disaster event in Pangandaran

Based on BPBD data, in 2018, recorded as many as 110 catastrophic events, including floods two times, strong winds as 48 times, landslides as much as ten times, and fires as much as 50 times. Nevertheless, the incident has explained that the area of Pangandaran Regency is in disaster-prone areas.

Then, Pangandaran Regency has vulnerable areas affected by the tsunami, because Pangandaran is on the sensitive area of earthquakes. The potential earthquake affects the tsunami. Tsunami threat is always lurking the coastal regions in South Java, including Pangandaran Regency; it is because Pangandaran district has 91 kilometers of beaches, but the anticipation in early detection of tsunami only with the help of 2 units of Early Warning System (EWS).
The potential danger of earthquakes and tsunamis for Pangandaran Regency caused the Indo-Australian plate to the north by 6-7 cm per year (Natawidjaja, 2007), which is the time of the Eurasian Plate. The movement could trigger a magnitude earthquake of $6 \mathrm{Ms}$ (natural disasters in Indonesia and its appearance, 2007). Even based on the field of several areas in Pangandaran Regency that has a high risk of natural disasters, such as villages that are in the area of West Pangandaran and East Pangandaran have a high risk of earthquakes and Tsunami.

With the condition of the region that is in the area vulnerable to natural disasters, several efforts have been made in the district of Pangandaran in disaster mitigation. Some of them are done by doing infrastructure development, and there is also doing it by conducting a pattern of empowerment or mentoring so that people are conscious and ready to face natural disasters.

So the mitigation that has been done is categorized into two categories, namely structural mitigation and nonstructural mitigation. Government agencies involved in disaster management in Pangandaran Regency include the following: Regional Development Planning Agency, Health Service Agency, Social Service Agency, Regional Secretariat for Social Affairs, Education Agency, Public Works Agency, and the Civil Service Police Unit (Satpol PP).

In addition to elements within the Pangandaran Regency government environment, the response to earthquakes, tsunamis, landslides or floods has also involved international organizations and community elements consisting of nature lovers groups, SAR teams, NGOs and communities engaged in disaster management, and also the people who live in the disaster area itself.

\section{Mitigation Efforts in Pangandaran Regency}

The mitigation is done to reduce the risk caused by the disaster. In the disaster management cycle, mitigation becomes part of the pre-disaster stage. But it does not rule out the possibility of mitigation can be carried out in line with the process of disaster management cycle carried out. Because the disaster management cycle, as described in Law No. 24 of 2007 concerning Disaster Management, is divided into Pre-disaster, Emergency Response, and PostDisaster.

This cycle is divided based on disaster events. In the implementation of disaster management, each phase continues to increase, from assessments to get disaster data, continued treatment, then evaluate what has been done. Mitigation is part of every process carried out in disaster management.

Mitigation is part of every procedure carried out in disaster management and conducted from the pre-disaster process, then the emergency response process if a disaster has occurred. In this process, mitigation is also upgraded, because mitigation that has been carried out in pre-disaster can be seen to be successful when a disaster occurs. See 
whether mitigation has an impact on the emergency response process.

Even mitigation continues even though it has entered the post-disaster stage, namely rehabilitation and reconstruction. Mitigation will adjust to the condition of the community and its environment after a disaster occurs. This upgrading process is to get better mitigation results. Thus mitigation for disaster management can include steps in pre-disaster emergency response and post-disaster then experience upgrading at each stage so that more can reduce the risk of disaster impacts at each stage.

\section{Structural Mitigation}

Structural mitigation carried out in natural disaster management in Pangandaran Regency is a series of efforts made by stakeholders to minimize the impact of disasters that occur in Pangandaran through physical development and by using a technological approach. Following are some of the events that have been carried out, including:

1. Building a Temporary Evacuation Building

Disaster mitigation efforts in Pangandaran Regency are needed because Pangandaran Regency is a coastal area that makes it the location of sources of earthquakes and even tsunamis. Risk management must focus on protecting the population from tsunami waves by careful mapping of potentially exposed areas and essential objects in appropriate risk mitigation efforts (Heriyanto, 12 November 2019)

Mitigation is realized by building a shelter or Temporary Evacuation Building (Tempat Evakuasi Sementara/TES) for coastal areas (Chaeroni, 2013), such as Pangandaran Regency. This building must be located on land very quickly to be reached by all people, especially when there will be a tsunami or earthquake. TES locations can generally be in the form of highland natural areas, areas of artificial high land, and new structures designed to withstand earthquakes and tsunamis.

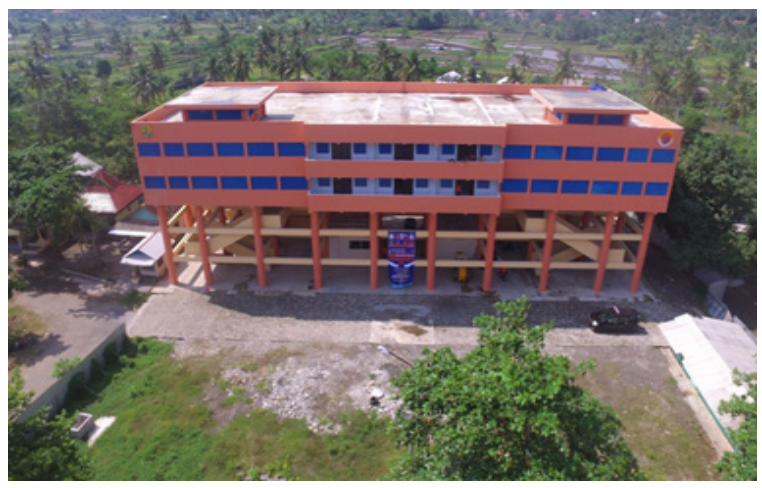

Source: BPBD, Pangandaran, 2019

Figure 2. Temporary Evacuation Building in Pangandaran Regency

The existence of a tsunami shelter or Temporary Evacuation Building (Tempat Evakuasi Sementara/TES) built-in tourist market area needs to be appreciated because the magnificent building is prepared to accommodate the community near the coast if at any time a tsunami disaster occurs.

Buildings with a total budget of around Rp 29 billion were sourced from the Ministry of Public Works and Public Housing of the Republic of Indonesia (PUPR) and the National Disaster Management Agency (BNPB) for the 2015-2016 fiscal year, with building capacity to accommodate 6000 refugees.

As revealed by informants from the BPBD, explaining the existence of this TES is a gathering point for people affected by the disaster, especially the tsunami. Even though TES has not yet been utilized, the condition of the building is still well maintained and clean. The TES building is always controlled, and cleanliness is always maintained even for the area around the TES is still full, and the surrounding area is protected from illegal structures.

The development of TES is one of structural mitigation because the mitigation carried out is a physical building that aims to reduce the impact of disasters, especially tsunamis. The TES was built not to be a final evacuation site but only a temporary evacuation site. Therefore this building must not be far from the coastline. As in Pangandaran Regency, the distance from the coast is approximately 500 meters.

2. Installation of Early Warning System (EWS) with control center located in BPBD and BMKG offices

EWS installation is included in the category of structural mitigation because it takes the form of physical development. EWS is the main building in detecting early if a tsunami disaster occurs.

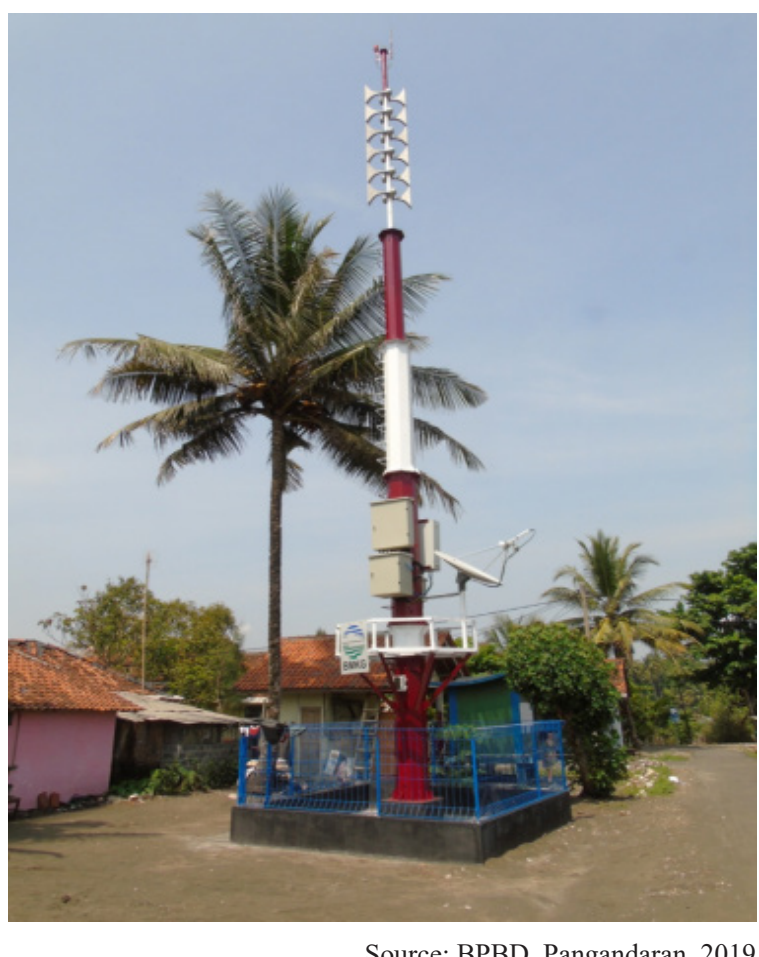

Figure 3. Early Warning System building in Pangandaran Regency 
Early Warning System is a system that aims to provide a warning to the community so that the community is ready to evacuate in the event of an earthquake and tsunami or notify the results of monitoring the occurrence of natural phenomena that can be disasters or other natural signs.

Pangandaran Regency is in an area prone to earthquakes and tsunamis, then EWS becomes a physical building that is important to minimize the occurrence of victims in case of disaster. This condition is urgent so that EWS must exist in tsunami-prone areas such as Pangandaran Regency. With the sophistication of EWS information technology, BPBD Pangandaran Regency expects that early warning systems can reach a broad and fast facing the changes that occur. So that the early warning system can anticipate the effects and risks of tsunamis. The installed EWS tool is a form of structural mitigation because EWS tools include efforts to reduce the occurrence of vulnerability to tsunami disasters through technical engineering through tsunami early warning assistance tools. So the installation of EWS tools includes structural mitigation because it is a form of reducing the occurrence of vulnerability to disasters through technical engineering (Sugiharyanto, 2014).

\section{Mitigasi Non-Structural}

Non-structural mitigation is another form of mitigation in the effort to reduce the impact of the disaster in Pangandaran Regency. The scope of this mitigation includes efforts to make policies or rules that can be used as guidelines for the community in reducing disaster risk. Not only in the form of policies but can be in the form of values held in the community, which is considered to reduce the risk of natural disasters in the area. From this experience, local people generally have local knowledge and ecological wisdom in predicting and mitigating natural disasters in their regions. Local knowledge is gained from rich experience due to interacting with ecosystems. The following non-structural mitigations have been carried out including:

1. Goes To School Disaster Education Tour (GTS WEB/Wisata Edukasi Bencana)

This program is intended for elementary school students in Pangandaran Regency. This activity is conducted by providing educational disasters through animated films then give material about the types of disasters that exist in Pangandaran, the characteristics of disasters, how to cope with disasters, and how to save themselves when disasters occur.

This activity held by BPBD, which is assisted by volunteers, even by students who are conducting activities of devotion or research in Pangandaran Regency. As revealed by the head of BPBD Pangandaran Regency that this educational tourism has content about disaster hazards and disaster preparedness so that the community can be resilient to disaster. It is then considered more effective if it is through the education of children. If done directly to the parents, it is the difficulty, especially getting routine time that can be attended by the target community.

Knowledge about disasters provided to school children will be more effective because it is right on target, and the number of goals is precise. The children can influence the environment in their families regarding disaster and become a provision for themselves in the future.

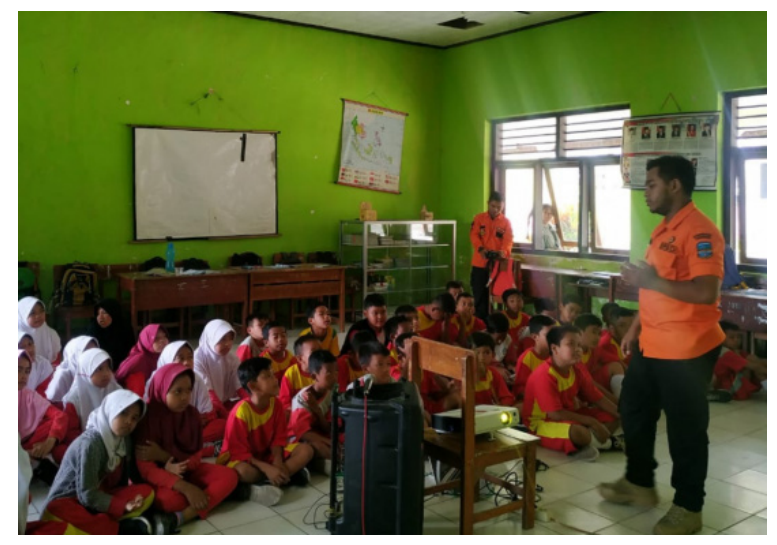

(Source: BPBD, Pangandaran, 2019)

Figure 4. Education Provided by Pangandaran Regency BPBD Members to School Children

2. Mother Learning Mitigation (BBM/Bunda Belajar Mitigasi)

Another form of non-structural mitigation undertaken by the Pangandaran Regency government is the implementation of the Mother of Mitigation Learning program.

Women are elements of society that have very high mobility and potential. They are active in community organizations that directly with basic community services, such as Posyandu (Pos Pelayanan Keluarga BerencanaKesehatan Terpadu/ Integrated Family Planning-Health Service Post), PKK (Pemberdayaan Kesejahteraan Keluarga/ Empowerment of Family Welfare) activities. They are become community mobilizers for activities and empowering community members to progress towards better social change.

Then the Mother of Mitigation Learning program is a mitigation program specifically for PKK mothers. The form of this program is andragogy training. This program aims to increase understanding of disaster risk and disaster management, improve government synergy with the PKK as partners in the process of disaster management, then create PKK members to be the leading agents to assist communities resilient in the face of disasters.

\section{Mitigation Kindergarten Children (Anak TK Mitigasi/ATM) \\ Not just parents, children as early as possible should} be used by knowledge around disdain to recognize the potential disasters in their surroundings. This program is 
in contrast to the Disaster Education program, the cause of this nonstructural migrating focuses on improving the understanding of kindergarten children concerning the disaster.

Therefore, BPBD Pangandaran Regency provides education to kindergarten students about the basics of the disaster, which is packaged with storytelling methods. Children practice material that illustrates the conditions of reality when faced with disaster.

Kindergarten children who are in the age range of 4-6 years have the best memory, some even say at that age is the golden age of humans (golden age). Childhood is a time of learning and learning; yet this time, the child begins to learn to imagine pouring all ideas and ideas into his game. Based on this thought, the Pangandaran Regency BPBD provided the Mitigation of Kindergarten children's activities.

By providing disaster education to kindergarten children with a different method from classroom learning. Children are invited to play while being introduced to disasters. Then through storytelling or fairy tales in which there is education about the disaster.

\section{Empathy For Sharing Disaster Education (Silaturahmi Empati Berbagi Edukasi Bencana/Si Embeb)}

"SI EMBEB" or the relationship of empathy sharing disaster education is one of the programs belonging to BPBD for middle and high school students. This form of mitigation includes non-structural mitigation, as it emphasizes education to students. The goal is to introduce potential disasters in the surrounding environment, the form of anticipation in disaster relief, disaster signs, way of handling in disaster conditions, and how to save themselves from disasters.

The program has a method used in the form of Group Dynamics, Group Communication, How to Fast to Know People and Groups, Disaster Countermeasures as well as not miss Trauma Healing. Performed by BPBD employees of Pangandaran Regency is also assisted by volunteers from both students and volunteers from the community.

The form of education became a priority activity conducted by the Pangandaran District BPBD. It is as BPBD parties have stated that this activity is a priority cause it is considered more effective and efficient. Even educational activities are more accessible at measuring its success, as events are conducted in schools. Those that are targeted can already be measured both from the sum and from the level of its education. Education is done each week by changing schools.

5. Inspection of fire protection equipment and building safety

This activity is intended to conduct the examination of fire protection and building safety equipment in Pangandaran Regency. Every incident of disaster is a fire that must be addressed quickly and must be right either by the building occupants or by the firefighters. Then the building must also have a building safety system; if there is a disaster or tsunami, the building has a unique path that is safe for the building occupants to evacuate themselves to a safer place.

Therefore, this activity becomes important to be carried out, especially for building managers who enter disaster-prone areas. The event began to assess the availability of fire protection equipment, especially in the BPBD building itself. Then new to other buildings. Even the hotel businessmen and entrepreneurs in the trading sector on the coast already have an awareness of disaster.

The awareness of hotel managers around Pangandaran regarding disastrousness can be seen with a large number of requests from hotel managers to get disaster mitigation training. The training also contains to view fire protection test tools and the safety of the building at the hotel. The BPBD has not been able to impose sanctions on hotels or structures that do not yet have fire protection and building safety equipment. But BPBD always gives an appeal so that managers can fulfill it because it is part of the best service to visitors.

This mitigation activity has the utilities of which there is clarity of safeguarding against disasters and reducing disaster risks, also to support Pangandaran as a world-class tourism District. Cause the building or hotel has safety standards for visitors, namely fire protection tools and building safety.

Also, this activity started from the BPBD building, because it is expected that BPBD offices serve as an example for the entire related agency to raise awareness of the importance of prevention of the disaster of the rawness through inspection of fire protection equipment.

Mitigation by inspecting buildings includes nonstructural mitigation because it is carried out to inventory buildings in Pangandaran Regency that have met building standards that are ready to face disasters, such as having fire protection and building safety standards.

\section{Earthquake and Tsunami Evacuation Simulation Training}

It is a two-year routine training activity for early warning systems and tsunami mitigation for country countries along the shores of the Indian Ocean.

Including in Pangandaran Regency, this exercise is done to realize the community in evacuation if the disaster. It is hoped that the implementation of a routine program that is done every 2 years will be valuable input for the improvement proposal of Tsunami Masterplan Indonesia, which is drafting the Indonesia agenda in the improvement of disaster management system Tsunami in the Indian Ocean region. This training is also conducted by the parties who have a concern for disasters in Pangandaran Regency.

Everyone is at risk for disaster, so disaster management is a concern for everybody's business. Therefore, 
sharing of roles and responsibilities in the level of preparedness at all levels, be it children, teens, and adults. It aims to raise awareness of disaster preparedness. The process of awareness is useful so that everyone can understand the risks, be able to manage threats and, in turn, contribute to the resilience of the community against the threat of disaster (BNPB, Handbook on Disaster Preparedness Exercise, Building Awareness, Alertness, and Preparedness in Dealing with Disasters, 2017).

Thus the non-structural mitigation carried out in Pangandaran District among them is the activity of Earthquake and Tsunami Evacuation Exercise. Cause these activities to have non-physical disaster risk reduction efforts such as, community empowerment or strengthening of institutions that will have full involvement when an earthquake or tsunami disaster occurs (Sugiharyanto, 2014).

\section{Disaster Training For Village Apparatus}

The BPBD has special activities shaped training for the village apparatus. This activity was to conduct coaching and training to the village apparatus to participate in disappointment. BPBD teams will provide sciences of dissatisfaction among them Pusdalops-PB Pangandaran Tupoction, How to Report Results Assessment, Criteria Damage, How to Use GPS (Global Positioning System), How to Communicate Using Handy Talky and the last of ground navigation by participants.

The objectives with the training and training for the village apparatus and the Community Protection Officer (Linmas/Hansip) are to be able to implement disaster knowledge gained in daily life. Because the village apparatus is the spearhead of every service to the community. This is because the village is closest to the community; the problems in the community are well understood by the village so that in the event of a disaster, the village officials and Linmas/Hansip in the village can participate quickly to mitigate the impact of the disaster.

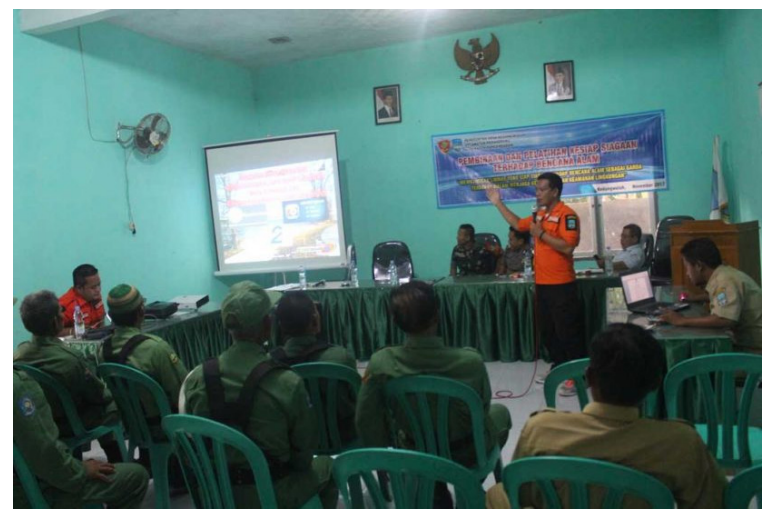

Source: BPBD, Pangandaran, 2019

Figure 5. Training of Village Apparatuses in Pangandaran Regency

The purpose is to provide training and training for the village apparatus, and this Community Protection Officer (Linmas / Guard) can implement the knowledge gained in daily life because the village apparatus became the spearhead of every service to the community. The village is very close to the people, the problem is very much understood by the village, so in the event of a disaster, the village apparatus and the guard in the village can participate quickly to counter the impact of the disaster.

\section{Disaster Management Operations Control Center} (PUSDALOPS) as Processor of Disaster Data Centers

Pusdalops as a source of disaster event data providers must have complete and accurate data, therefore the need for standardization in data processing to facilitate data processing from the regions and centers in Pangandaran Regency.

The Center for Disaster Management Operations Control or abbreviated as PUSDALOPS PB Pangandaran Regency was established on January 3, 2017. The main tasks and functions are following the Regulation of the Head of BNPB No.15 of 2012 in Pre-Disaster to provide support for activities before the disaster (collectors, processors, data presenters and provide information disaster) routinely, When Disaster offers support to the emergency response post and the implementation of emergency activities. Post-Disaster provides support for activities in the aftermath of a disaster (data and information providers, especially in the implementation of rehabilitation and reconstruction).

Information and data received by Pusdalops PB processed examined and visualized to be submitted to stakeholders, especially in Pangandaran Regency, generally in Indonesia. PB Pusdalops is led by a Manager who is directly responsible to the supervisor. In carrying out its task Manager, Pusdalops PB assisted by supervisors and operators. Pusdalops PB in the service of information and data in the field of disaster conducting 24-hour community services, in addition to carrying out the main task Pusdalops PB to deliver information through programs of disaster mitigation innovations that described earlier.

Mitigation in tourist areas, which is the main point, is the safety of tourists. The involvement of tourists in mitigation carried out in Pangandaran Regency has not been much, tourists can only feel the structural model of disaster mitigation programs, only in the form of evacuation signs applied by the government in crowded places and also in hotels, such as signs to Temporary Evacuation Places (TES) which was designated as the first evacuation site at the time of the tsunami. While the involvement of tourists in non-structural mitigation has not been carried out comprehensively, only announcements made by hotel managers.

Thus, mitigation is undertaken still needs to be strengthened, especially strategies in carrying out the empowerment process in disaster mitigation that is part of preventive efforts in natural disasters. According to Pramono (2016) If disaster management strategies are a 
reference in human behavioral responses or social groups in the face of a catastrophic threat becomes more effective, then the strategy needs to be developed and applied into a living part of humans or groups that experience a catastrophic threat in daily life. Pramono leaned to make disaster management a preventive measure in aspects of everyday life.

Mitigation made in Pangandaran Regency is part of an effort from thorough and proactive efforts of natural disasters management, starting from disaster risk reduction, emergency response, and rehabilitation and reconstruction. The Pangandaran Regency's wisdombased disaster mitigation capabilities are supported by its local government policies.

\section{CONCLUSION}

Pangandaran has a reasonably high disaster risk index to 16 disaster-prone from 514 Indonesian cities/regencies. As for the frequent disasters in Pangandaran in the last ten years of time, floods, tidal waves, droughts, earthquakes, landslides, tornadoes, and forest fires. To reduce the risk of disaster, the government, through BPBD, has been organized disaster mitigation with two models, namely structural mitigation, namely physical development such as the TEST building (temporary evacuation site) and building an Early warning system. Other models are non-structural mitigation, which is the mitigation of regulations, counseling, education, and also the provision of information about the disaster. But there are still shortcomings, especially the involvement of tourists in mitigation. Then comprehensive disaster mitigation is needed that is carried out jointly by stakeholders with complementary roles and functions. Comprehensive mitigation is part of the development process to realize community resilience to disaster.

\section{REFERENCES}

BNPB. (2008). Regulation of the Head of the National Disaster Management Agency Number 4 of 2008 concerning Guidelines for the Preparation of Disaster Management Plans. Jakarta.

BNPB. (2017). Handbook on Disaster Preparedness Exercise, Building Awareness, Alertness, and Preparedness in Dealing with Disasters (2nd Edition ed.). Jakarta: Directorate for Preparedness Deputy for BNPB Prevention and Preparedness.

BPBPD Kabupaten Pangandaran. (2019, August 15). https://bpbd.pangandarankab.go.id/download/ rekap-data-kejadian-bencana-kabupatenpangandaran-tahun-2014-2019/.(BPBD Kabupaten Pangandaran) Retrieved January 2, 2020, from https://bpbd.pangandarankab.go.id.

Chaeroni, W. H. (2013). Tsunami Modeling and Making Immersion Maps for Mitigation Needs in Teleng
Bay, Pacitan. Jurnal Penanggulangan Bencana, 4, (2), 23-33.

Faturahman, B.M. (2018). Conceptualization of Disaster Mitigation through Public Policy Perspectives. PUBLISIA: Jurnal Ilmu Administrasi Publik, 3 (2), 122-134.

Heriyanto, R.W. (12 November 2019). Mapping Management of Geographic Information Systems Distribution of Post-Earthquake Disaster Areas in Padang Pariaman Regency. Proceeding of the National Seminar on Information Technology, Communication and Industry (SNTIKI) II.ISSN (Online): 2579-5406. Pekanbaru: Faculty of Science and Technology, UIN Sultan Syarif Kasim Riau.

Herry. (2018, January 11). http://www.koransinarpagijuara. com/2018/01/11/dpkpb-per Check-alat-proteksikebakaran-hotel-di-pangandaran/. (Sinar Pagi) Retrieved January 2, 2020, from http://www. koransinarpagijuara.com.

Kemendagri. (2006). Attachment of Regulation of the Minister of Home Affairs Number 33 of 2006 Dated October 18, 2006, Regarding Guidelines for Disaster Mitigation. Jakarta: Kemendagri.

Kusnadi,A.(2018,February2).https://kabarpriangan.com/ bunda-learn-mitigation- improve- preparednesscommunity/. (kapol.co.id) Retrieved January 3, 2020, from https://kabarpriangan.com.

Mulyadi. (2012). Traumatic Response of Children of Banjir Bandang Victims in Wasior, West Papua. Sosiohumaniora, 14, (1), 12-23.

Neuman, W. (2006). Social Research Methods: Qualitative and Quantitative. 6th ed. Boston: Allyn and Bacon.

Nursa'ban, S. (2010). Measurement of Landslide Vulnerability as Disaster Mitigation Efforts in Menoreh Hills. Saintek Research Journal, 15, (2), 42-52.

Pangandaran News. (2017, April 26). http://www. pangandarannews.com/2017/04/pangandaranmiliki-tes-berkapasitas.html. Retrieved January 12, 2020, from http://www.pangandarannews. com.

Pangandaran, G.O. (2018). LKIP Pangandaran Regency Government in 2018.

Pramono, R. (2016). Sociological Perspective in Disaster Management. Jurnal Masyarakat dan Budaya, 18, (1), 81-96.

Sugiharyanto, W.T. (2014). Social Sciences Students' Perception of Earthquake Disaster Mitigation. JIPSINDO, 2, (1), 164-182. 
Sumaryana, A.U. (2018). Socialization of Collaborative Models in Natural Disaster Management in Pangandaran Regency. Dharmakarya: Journal of Science and Technology Applications for Communities, 7, (2), 134-137.

Sumaryana, A.U. (2019). Creating Sustainable Disaster Management Collaboration In Indonesia.
International Journal of Civil Engineering and Technology (IJCIET), 10, (02), 2435-2440.

Triana, D.T. (2017). Disaster Mitigation Through Cultural and Structural Approaches. Proceedings of the XII National Seminar "Industrial Engineering and Information Technology 2017 Yogyakarta National College of Technology. 